\title{
The identification of variables which universally and significantly influence the return on assets (ROA) of retail pharmacies in South Africa
}

\author{
J. Marx \\ Department of Business Economics, University of South Africa, P.O. Box 392, Pretoria 0001, Republic of South Africa
}

Received November 1992, accepted May 1993

\begin{abstract}
A retail pharmacist who wishes to ensure the long-term survival of his or her business in a free enterprise system must make the pharmacy's profitability the prime objective. In South Africa, the profitability of retail pharmacies and, thus, of their continued operation, are threatened by increasing competition among retail pharmacies and from dispensing doctors. Nonetheless, the profitability can be enhanced even in these circumstances by adopting a strategic management approach. The research hypothesis of this article is that there are specific controllable internal strategic management variables which universally and significantly influence the return on assets (ROA) of South African retail pharmacies. Multiple regression analysis was used in the study and it was found that the variance in the ROAs of South African retail pharmacies is explained by several strategic management variables. These are associated significantly (on a 5\% level) with pharmacies' ROA and include variables such as the sole proprietorship and the partnership as forms of business organization, the purchase ratio and the analysis of strengths and weaknesses as part of their strategic management. Mark-up pricing and the closed corporation as a form of business organization are negatively related to ROA.

'n Kleinhandelapteker wat die langtermyn-voortbestaan van sy of haar onderneming in 'n vryemarkstelsel wil verseker, moet die winsgewendheid daarvan as primêre doelstelling nastreef. In Suid-Afrika word die winsgewendheid en corlewing van kleinhandelapteke deur toenemende mededinging tussen apteke onderling en deur resepterende geneeshere bedreig. Desnieteenstaande kan die winsgewendheid van apteke gehandhaaf word deur 'n strategiese bestuursbenadering toe te pas. Die navorsingshipotese van hierdie artikel is dat spesifieke, beheerbare interne veranderlikes betreffende strategiese bestuur bestaan, wat die opbrengs op bates (ROA) van Suid-Afrikaanse apteke universeel en beduidend beinvloed. Meervoudige regressie-analise is in die studie gebruik en daar is bevind dat die variansie in die ROA's van Suid-Afrikaanse apteke deur verskeie veranderlikes betreffende strategiese bestuur verklaar kan word. Hierdie veranderlikes toon 'n beduidende verband (op 'n peil van 5\%) met die ROA's van apteke en sluit veranderlikes in soos die eenmansaak en vennootskap as ondernemingsvorme, die aankoopverhouding, en die ontleding van sterk en swak punte van die onderneming as deel van strategiese bestuur. Die toeslagmetode van prysbepaling en die beslote korporasie as ondernemingsvorm toon 'n negatiewe verband met ROA.
\end{abstract}

\section{Problem definition}

In order to ensure the continued existence of a retail pharmacy in a free enterprise system, the pharmacist has to pursue the profitability of his/her' pharmacy (Futter, 1990: 6).

The profitability and survival of the retail pharmacy business is threatened by increasing competition among retail pharmacists and between retail pharmacists and dispensing doctors. The number of retail pharmacies in South Africa has increased from 2465 in 1985 to 2843 in 1991 - an increase of $15 \%$ over this period. The role of dispensing doctors should, however, also be taken into consideration when evaluating the increased competition in this sector. The number of dispensing doctors registered with the South African Medical and Dental Council has increased from 3594 in 1985 to 6879 in 1991 - an increase of $91 \%$. The biggest increase occurred in the Transvaal where the number of registered dispensing doctors has increased by $124 \%$ since 1985.

A strategic management approach can have a positive influence on the profitability of retail pharmacies. This assertion is based on several studies conducted in the United States of America ${ }^{2}$ concerning improved profitability brought about by implementing a strategic management approach (Pearce \& Robinson, 1988: 17-19; Byars, 1987: 6, 8). The conclusion reached was that organizations with formal strategic management systems outperformed others on earnings per share, return on assets and return on equity.
The performance of these organizations from the time they initiated formal strategic management systems was also compared with their performance over an equal period of time prior to the initiation of the systems (Byars, 1987: 8). The post-initiation performance of these companies surpassed their performance in prior years. It therefore seems clear that the prudent retail pharmacist should adopt a strategic management approach in order to ensure the survival of his pharmacy.

The significance of a strategic management approach is that it addresses the core responsibility of the retail pharmacist, which is to ensure the profitability of the pharmacy today and in the future. The retail pharmacist must continuously survey the environment, determining the nature of the pharmacy, setting goals for it, devising policies and strategies to achieve these objectives, and assuring that action is taken in such a way that the policies and strategies decided upon result in the achievement of the objectives (Steiner, et al. 1986: 242).

The strategic management approach requires the formulation of master and functional strategies. The master strategy gives general direction, while the functional strategy spells out what specific results should be achieved. The master and functional strategies are designed to take advantage of markct opportunities and neutralize adverse environmental impacts. At the same time, they reinforce the internal strengths of the pharmacy and improve on its perceived weaknesses relative to its competitors (Byars, 1987: 92). 
The purpose of this article is to identify and evaluate variables which universally and significantly influence the return on assets (ROA) of retail pharmacies in South Africa.

The research hypothesis is that there are specific controllable intemal variables related to strategic management which universally and significantly influence the ROA of retail pharmacies in South Africa.

\section{Methodology}

\section{Structured questionnaire}

A structured questionnaire was used for the following reasons:

1. Structured questionnaires are self-explanatory and can be completed more quickly than is the case with unstructured questionnaires.

2. Questionnaires are more economical to use than interviews or observations.

3. A structured questionnaire involves relatively few instructions.

\section{Population}

At the time of selecting a sample, the total population of retail pharmacies in the Republic of South Africa numbered 2775 . These were distributed as indicated in Table 1.

Table 1 The distribution of pharmacies in South Africa according to promotion chain and province

\begin{tabular}{lrrrrrr}
\hline & \multicolumn{7}{c}{ Family } & & & & \\
Province & Bonus & Circle & Link & Plus & Other & Total \\
\hline Transval & 0 & 126 & 218 & 424 & 674 & 1442 \\
Cape Province & 182 & 37 & 194 & 71 & 242 & 726 \\
Natal & 0 & 39 & 72 & 184 & 116 & 411 \\
Orange Free State & 0 & 22 & 13 & 56 & 85 & 176 \\
\hline Total & 182 & 224 & 497 & 735 & 1117 & 2755 \\
\hline
\end{tabular}

\section{Sample size}

For the sample to be representative, a proportional number of retail pharmacies for each province, metropolitan area, city and town in South Africa, as well as each type of pharmacy, should be included in the sample. In order to ensure representativeness, a stratified random sample consisting of 800 retail pharmacies, according to the area ${ }^{3}$ and type of pharmacy, ${ }^{4}$ was selected. The calculation of the sample sizes for each of the provinces, metropolitan areas, cities and rural towns were done consecutively using a Lotus 1-2-3 spreadsheet (see Table 2).

\section{Response}

The questionnaire was sent to the sample of 800 retail pharmacies. The respondents numbered 258 , representing a response rate of $32.25 \%$. This compares favourably with the response rate of $27.55 \%$ achieved by the Bureau of Financial Analysis (BFA) (1983: 75) when they conducted a survey among retail pharmacists. The South African Pharmaceutical Society achieved a $10 \%$ response rate on a questionnaire which had been sent to retail pharmacies six
Table 2 The proportional sample sizes according to promotion chain and for the various provinces

\begin{tabular}{|c|c|c|c|c|c|c|}
\hline \multirow[b]{2}{*}{ Province } & \multicolumn{3}{|c|}{ Family } & \multirow[b]{2}{*}{ Plus } & \multirow[b]{2}{*}{ Oher } & \multirow[b]{2}{*}{ Total } \\
\hline & Bonus & Circle & Link & & & \\
\hline Transvaal & 0 & 37 & 63 & 123 & 196 & 419 \\
\hline Cape Province & 53 & 11 & 56 & 21 & 70 & 211 \\
\hline Natal & 0 & 11 & 21 & 53 & 34 & 119 \\
\hline Orange Free State & 0 & 6 & 4 & 16 & 25 & 51 \\
\hline Toul & 53 & 65 & 144 & 213 & 325 & 800 \\
\hline
\end{tabular}

months prior to the distribution of the questionnaire involved in this study.

The sample realization is tabulated in Table 3. Respondents were not proportionate to the sample originally selected. This was corrected by weighing the responses. The weights used in this study are reported along with the sample realization (responses) - see Table 3 .

\section{Method of anaiysis}

Given the objective and the nature and number of variables involved in this study, it was decided to use multiple regression analysis to analyze the data. Multiple regression analysis is a statistical tool for evaluating the relationship or association between one or more independent variables with a single continuous dependent variable by means of a mathematical model (Kleinbaum \& Kupper, 1978: 34). Models developed by means of this technique not only describe relationships, but can also be used for making predictions. The independent variables are therefore also known either as predictors or as explanatory variables. In this study the emphasis is on the establishment of associations, meaning that the independent variables included in the models are used for explanatory purposes and not for making predictions.

The general format of a multiple regression model is as follows:

$Y_{i}=b_{0}+b_{i} X_{1}+b_{i} X_{2}+\ldots+b_{k} X_{a}+e_{i}$

where:

$$
\begin{aligned}
\mathbf{Y} & =\text { dependent variable } \\
\mathbf{b}_{\mathbf{b}} & =\text { intercept or constant term } \\
\mathbf{b}_{\mathbf{i}} & =\text { regression coefficient for variable } \mathrm{X}_{\mathbf{i}} \\
\mathrm{X}_{1}, \mathrm{X}_{2}, \ldots, \mathbf{X}_{\mathbf{k}} & =\text { independent variables } \\
\mathrm{i} & =1,2, \ldots, \mathbf{n} \\
\mathbf{n} & =\text { number of observations } \\
\mathrm{e} & =\text { residual }
\end{aligned}
$$

If $x_{1}, \ldots, x_{k}$ represent the observed values of $X_{1}, X_{2}, \ldots$, $X_{k}$, then the predicted value $Y$ of $Y$ applies so that

$Y=b_{0}+b_{1} X_{1}+\ldots+b_{k} x_{n}$

The principal difference between multiple regression and simple regression is that simple regression can be plotted in a two-dimensional space, while a multiple regression model forms a hyperplane through multidimensional space. Each 
Table 3 The calculation of weights based on the ratio of the sample versus responses

\begin{tabular}{|c|c|c|c|c|c|}
\hline $\begin{array}{r}\text { Province } \\
\text { (1) }\end{array}$ & $\begin{array}{c}\text { Type of } \\
\text { phamacy } \\
\text { (2) }\end{array}$ & $\begin{array}{l}\text { Area } \\
(3)\end{array}$ & $\begin{array}{c}\text { Sample } \\
\text { (4) }\end{array}$ & $\begin{array}{l}\text { Responses } \\
\text { (5) }\end{array}$ & $\begin{array}{l}\text { Weight } \\
(4) /(5)\end{array}$ \\
\hline & Farnily Circle & Metro's \& cities & 10 & 4 & 2.5 \\
\hline & & Towns & 27 & 13 & 2.0769 \\
\hline & Link & Metro's \& cities & 20 & 6 & 3.3333 \\
\hline & & Towns & 44 & 13 & 3.3846 \\
\hline \multirow[t]{7}{*}{ Transvaal } & Plus & Metro's \& cities & 53 & 9 & 5.8888 \\
\hline & & Towns & 70 & 26 & 2.69 \\
\hline & Other & Metro's \& cities & 99 & 29 & 3.4137 \\
\hline & & Towns & 98 & 27 & 3.6296 \\
\hline & Bonus & Metro's \& cities & 27 & 13 & 2.0769 \\
\hline & & Towns & 25 & 8 & 3.125 \\
\hline & Family Circle & $\begin{array}{l}\text { Metro's, cities \& } \\
\text { towns }\end{array}$ & 11 & 4 & 2.75 \\
\hline \multirow[t]{10}{*}{ Cape Province } & Link & Metro's \& cities & 21 & 5 & 4.2 \\
\hline & & Towns & 33 & 11 & 3 \\
\hline & Plus & Metro's \& cities & 10 & 4 & 2.5 \\
\hline & & Towns & 11 & 5 & 2.2 \\
\hline & Oher & Metro's & 28 & 7 & 4 \\
\hline & & Cities & 11 & 3 & 3.6666 \\
\hline & & Towns & 31 & 7 & 4.4286 \\
\hline & Family Circle & $\begin{array}{l}\text { Metro's, cities \& } \\
\text { towns }\end{array}$ & 11 & 3 & 3.6666 \\
\hline & Link & Metro's \& cities & 8 & 2 & 4 \\
\hline & & Towns & 14 & 6 & 2.3333 \\
\hline \multirow[t]{6}{*}{ Natal } & Plus & Metro's \& cities & 25 & 10 & 2.5 \\
\hline & & Towns & 28 & 14 & 2 \\
\hline & Other & Metro's \& cities & 15 & 7 & 2.1429 \\
\hline & & Towns & 19 & 4 & 4.75 \\
\hline & Family Circle & Cities & 3 & 3 & * \\
\hline & & Towns & 3 & 1 & * \\
\hline \multirow[t]{6}{*}{ OFS } & Link & Cities & 1 & 0 & * \\
\hline & & Towns & 3 & 0 & * \\
\hline & Plus & Cities & 5 & 1 & * \\
\hline & & Towns & 11 & 6 & * \\
\hline & Other & Cities & 13 & 4 & * \\
\hline & & Towns & 12 & 3 & * \\
\hline \multicolumn{2}{|c|}{ Total } & & 800 & 258 & - \\
\hline \multicolumn{2}{|c|}{$\%$ of total } & & 100 & 32 & 一 \\
\hline
\end{tabular}

* The weights for the respondents from the Orange Free State were calculated as follows:

$$
\begin{aligned}
& \text { Cities } \quad=\frac{3+1+5+13}{3+0+1+4}=\frac{22}{8}=2.75 \\
& \text { Towns }=\frac{3+3+11+12}{1+0+6+3}=\frac{29}{10}=2.9
\end{aligned}
$$

regression coefficient represents a slope and it is not possible to present the multiple regression model visually if there are more than two independent variables.

Generally it is possible to increase the value of the coef- ficient of determination $\left(\mathrm{R}^{2}\right)$ by adding more explanatory variables to the regression model. However, not all explanatory variables make a significant contribution to explaining the variation in the dependent variable $Y$. In building a re- 
gression model, the number of explanatory variables should be limited to those that offer the best explanation for the variation in $Y$.

The regression coefficients or parameters of each of the models discussed in this study were estimated by means of the regression procedure (REG) of the Statistical Analysis Software programme (SAS). Explanatory variables for inclusion in a final model were selected objectively after repeatedly performing the general linear model (GLM) and REG procedures of SAS.

Residual analysis was performed to determine the aptness of each of the models. Aptness here refers to the degree to which the model satisfies the assumptions of regression analysis, namely that:

1. The residuals are independent.

2. The mean of the residuals is zero and the variance of the residuals is constant over the range of the independent variables.

3. The residuals are normally distributed.

The residual $(Y-\hat{Y})$ is the difference between the actual value of the dependent variable and the value predicted by the regression model. A residual value can be computed for each observation in the data set. The principal means of residual analysis is studying the residual plots. ${ }^{5}$ Possible outliers in the data set can also be identified by means of residual analysis.

Not all of the independent variables were continuous variables. This does not create problems when using the general linear model (GLM) procedure of SAS, because this procedure uses the CLASS statement to convert categorical variables to so-called 'dummy' or 'indicator' variables. A dummy variable is any variable in a regression equation that takes on a finite number of values for the purpose of identifying different categories of a categorical variable. The term 'dummy' simply relates to the actual values taken on by such variables ${ }^{6}$ and describes no meaningful measurement level of the variable; a dummy variable acts only to designate the categories of interest.

When applying the regression (REG) procedure, dummy variables must be defined for the categorical independent variables. The rule for the definition of dummy variables is as follows:

'If the categorical independent variable of interest has $k$ categories, then one must define $k-1$ dummy variables to index these categories, provided that the regression model contains a constant term (an intercept)' (Kleinbaum \& Kupper, 1978: 189).

The continuous variables were initially explored by means of the UNIVARIATE procedure of SAS, and the categorical variables by means of the frequency (FREQ) procedure before the construction of the regression model was embarked upon. The UNIVARIATE analysis provided, inter alia, the mean, first and third quartiles, as well as the ranges (the difference between the minimum and maximum levels) of the continuous independent variables. These ranges were needed for the calculation of indices of the variables included in the final regression models.

The following approach was then followed throughout to construct the regression models:
1. A first run was done with GLM and REG with all the independent variables included in the models.

2. From the printout obtained with the first run, independent variables with an exceedence pmbability smaller than 20\% $(P<0.20)$ were selected for inclusion in the next run. These variables contribute significantly (on a $20 \%$ exceedence probability) to the variation in the dependent variable.

3. After the second run, only independent variables with an exceedence probability smaller than $5 \%(P<0.05)$ were selected for inclusion in a third run of the model, to provide the final model.

The above-mentioned approach was followed to allow for one of the traits of multiple regression analysis, namely that the contribution of a variable to a model is influenced by the other variables which are simultaneously included in the model. The two runs served as a selection process to find the best possible model.

The regression coefficients of the final regression model indicate the strength of an association between an independent variable and a dependent variable. Since the model was constructed for explanatory purposes, it does not have as high a coefficient of determination $\left(R^{2}\right)$ as would have been the case if the model had been constructed for prediction purposes.

The significance of the linear relationship between the dependent variable $(Y)$ and the set of explanatory independent variables $\left(X_{1}, \ldots, X_{k}\right)$ is measured by the multiple coefficient of determination, $R^{2}$. In other words, $R^{2}$ is the proportion of the variation of the dependent variable $Y$ that is explained by the explanatory variables $X_{1}, X_{2}, \ldots, X_{4}$ in a multiple linear regression.

In multiple regression analysis, the adjusted coefficient of variation (adj $R^{2}$ ) takes into account the relationship between the number of cases and the number of independent variables in the regression model. Whereas $R^{2}$ will increase when an independent variable is added, the adj $R^{2}$ will decrease if the added variable does not reduce the unexplained variation enough to offset the loss of degrees of freedom.

\section{Variables included in the multiple regression models}

A multiple regression model describes the relationship between a dependent variable and a set of independent variables. For the purpose of this article the dependent variable is the ROA of the retail pharmacies surveyed. Variables related to the functional strategies of retail pharmacists form the independent variables. Variables related to the location of the pharmacy, as well as those concerning the pharmacist, were also included in the models. The continuous and categorical independent variables included in each of the initial comprehensive regression models are set out in Tables 4 and 5 respectively. The weighted values of the observations are also included in the tables.

For the dependent variable, ROA, regression models were constructed according to the procedure described earlier and using a confidence level of $5 \%$ in the final model. This means that any independent variable that had an exceedence 
Table 4 Continuous independent variables for inclusion in regression models

\begin{tabular}{lrrr}
\hline \multicolumn{1}{c}{ Variable } & Quartile 1 & Mean & Quartile 3 \\
\hline Number of management courses attended by pharmacist & 0 & 1 & 2 \\
Number of years' experience of the pharmacist & 9 & 16 & 24.5 \\
Number of trading hours per week & 49.5 & 53 & 59.125 \\
Promotion expenditure & 412.5 & 1500 & 4075 \\
Percentage of sales that have to be delivered & 5 & 15 & 30 \\
Kilometres travelled to make deliveries & 10 & 45 & 100 \\
Size of pharmacy (measured in square meters) & 110 & 150 & 210 \\
Average number of prescriptions dispensed per day & 19.5 & 30 & 55 \\
Total number of full-time employees & 5 & 6 & 9 \\
Total number of part-time employees & 0 & 1 & 2 \\
Number of days of absenteeism & 7.5 & 17 & 40 \\
Personnel tumover & 0 & 1 & 2 \\
Number of grievances of personnel & 0 & 0 & 3 \\
Number of wholesalers purchased from & 3 & 10 & 25.5 \\
Value of purchases per buyer & 152669 & 214374 & 342375 \\
The critical order ratio & 0.33 & 0.5 & 0.66 \\
The percentage discount allowed to medical aid schemes & 15 & 15 & 17 \\
\hline
\end{tabular}

probability of less than $5 \%$ (i.e. the association had less than a $5 \%$ probability of being purely coincidentally associated with the dependent variable), was regarded as significantly associated with the dependent variable. The findings will now be discussed.

\section{Findings}

Indices to reflect the maximum partial influence that the explanatory variable may exent on the dependent variable were calculated. The following are the indices for the variables listed in Table 6.

The maximum ROA was 1.42577 (or 142\%) and the minimum -0.3221 (or $-32.21 \%$ ). Therefore the range $(\mathrm{Vy})$ equals 1.74787 .

Index for continuous variable:

$$
\begin{aligned}
\text { Purchase ratio } & =0.000000189 \cdot \frac{2153000}{1.74787 .100} \\
& =23.28 \%
\end{aligned}
$$

Indices for categorical variables:

$\begin{aligned} \text { Percentage mark-up pricing } & =\frac{-0.06-(-0.06)}{1.74787} \cdot 100 \\ & =-6.87 \% \\ \text { Sole proprietorship } & =\frac{0.12-(-0.12)}{1.74787} \cdot 100 \\ & =13.73 \% \\ \text { Partnership } & \\ & =\frac{0.01-(-0,01)}{1.74787} \cdot 100 \\ & =1.14 \%\end{aligned}$

Close corporation

$$
\begin{aligned}
& \frac{-0.07-(0.7)}{1.74787} \cdot 100 \\
= & -8 \% \\
= & \frac{0.034(0.034)}{1.74787} \cdot 100 \\
= & 3.89 \%
\end{aligned}
$$

Analysis of strengths and weaknesses done by

pharmacist

The regression coefficients for the ROA model can be graphically presented as in Figure 1.

\section{Interpretation and integration of findings}

From the above indices, the following interpretations can be made.

- If two pharmacies are compared, both having the same form of business organization, both applying the percentage mark-up as a method of pricing and both having analyzed their respective strengths and weaknesses, but differing with regard to the purchase ratio, then the maximum difference in their ROA would be $23.28 \%$.

- If, however, the two pharmacists had the same purchase ratio, operated as either a sole proprietorship, a partnership, or a close corporation, and had analyzed their respective strengths and weaknesses, but only one of them applied percentage mark-up as a method of pricing, then the ROA of the latter will at maximum be $6.87 \%$ lower than that of the other.

- If two pharmacists had the same purchase ratio, applied the percentage mark-up as a method of pricing and had analyzed their respective strengths and weaknesses, but only one of them operated as a sole proprietorship, then the latter could at maximum attain a $13.73 \%$ higher return than the other. Similarly, if two pharmacists had the same purchase ratio, applied the percentage mark-up as a 
Table 5 Categorical independent variables included in the regression models

\begin{tabular}{|c|c|c|}
\hline Variable & Calegory & $\%$ \\
\hline Location & $\begin{array}{l}\text { Central business district } \\
\text { Residential area }\end{array}$ & $\begin{array}{l}53.1 \\
46.9\end{array}$ \\
\hline Premises & $\begin{array}{l}\text { Medical centre } \\
\text { Shopping centre } \\
\text { Street front } \\
\text { Isolated }\end{array}$ & $\begin{array}{r}5.8 \\
26.1 \\
58.3 \\
9.8\end{array}$ \\
\hline Districl & $\begin{array}{l}\text { Metropolitan area or city } \\
\text { Rural town }\end{array}$ & $\begin{array}{l}43.5 \\
56.5\end{array}$ \\
\hline $\begin{array}{l}\text { Pharmacy } \\
\text { type }\end{array}$ & $\begin{array}{l}\text { Fanily Circle } \\
\text { Link } \\
\text { Plus } \\
\text { Bonus } \\
\text { Other }\end{array}$ & $\begin{array}{r}9.5 \\
17 \\
29.8 \\
6.9 \\
36.8\end{array}$ \\
\hline $\begin{array}{l}\text { Strategic } \\
\text { management }\end{array}$ & $\begin{array}{l}\text { Pharmacists who have defined their mission statement } \\
\text { Pharmacists who have not defined their mission statement } \\
\text { Pharmacists who have their mission statement in writing } \\
\text { Pharmacists who do not have their mission statement in writing } \\
\text { Pharmacists whose personnel are aware of the mission statement } \\
\text { Pharmacists whose personncl are not aware of the mission statement } \\
\text { Pharmacists who have set long-term objectives } \\
\text { Pharmacists who have not set long-term objectives } \\
\text { Pharmacists who have set shon-term objectives } \\
\text { Pharmacists who have not set shon-tem objectives } \\
\text { Pharmacists who have analyzed the strengths and weaknesses of their pharmacies } \\
\text { Pharmacists who have not analyzed the strengths and weaknesses of their pharmacies } \\
\text { Pharmacists who have analyzed the opportunities and threats of their phamacies } \\
\text { Pharmacists who have not analyzed the opportunities and threats of their pharmacies } \\
\text { Pharmacists who have a management information system } \\
\text { Pharmacists who do not have a management information system }\end{array}$ & $\begin{array}{l}74.1 \\
25.9 \\
13.9 \\
86.1 \\
68.3 \\
31.7 \\
57.2 \\
42.8 \\
80.6 \\
19.4 \\
75.3 \\
24.7 \\
79.5 \\
20.5 \\
62.5 \\
37.5\end{array}$ \\
\hline $\begin{array}{l}\text { Pricing } \\
\text { method }\end{array}$ & $\begin{array}{l}\text { Pharmacists who apply percentage mark-up } \\
\text { Pharmacists who do not apply percentage mark-up } \\
\text { Pharmacists who apply recornmended resale prices } \\
\text { Pharmacists who do not apply recommended resale prices } \\
\text { Pharmacists who apply the break-even method } \\
\text { Pharmacists who do not apply the break-even method } \\
\text { Pharmacists who apply going-rate prices } \\
\text { Pharmacists who do not apply going-rate prices }\end{array}$ & $\begin{array}{l}86.4 \\
13.6 \\
81.8 \\
18.2 \\
15.5 \\
84.5 \\
23.9 \\
76.1\end{array}$ \\
\hline
\end{tabular}

method of pricing and had analyzed their strengths and weaknesses, but only one of them operated as a partnership, then the latter could expect to attain an ROA $1.14 \%$ greater (at maximum) than the other operating as either a single proprietorship or close corporation.

- If two pharmacists had the same purchase ratio, applied the percentage mark-up as a method of pricing and analyzed their strengths and weaknesses, but only one of them operated as a close corporation, then the latter could expect to attain an ROA 8\% lower than the other operating as either a single proprietorship or a partnership.

- If two pharmacies had the same form of business organization, both applied the percentage mark-up as a method of pricing and both had the same purchase ratio, but only one of them had analyzed the strengths and weaknesses of his pharmacy, then the latuer could attain an ROA $3.89 \%$ greater than the other.

The purchase ratio gives an indication of how effectively purchasing is done. Depending on the level of sales, decisions concerning the purchasing of stock may be either delegated to sales assistants or centralized in the hands of the pharmacist. Delegating authority for purchasing decisions to sales assistants may be appropriate for pharmacies with high levels of sales because it leaves the pharmacist with more time for managing the dispensary and the other departments of his pharmacy. Time spent by the pharmacist on managing the dispensary and controlling the management of the pharmacy may positively influence its profitability. 
Table 6 Results of the regression model for ROA

\begin{tabular}{|c|c|c|c|}
\hline Independent variable & $\begin{array}{l}\text { Regression } \\
\text { coefficient }\end{array}$ & $\begin{array}{l}\text { Exceedence } \\
\text { probability }\end{array}$ & $\begin{array}{c}\text { Standardized } \\
\text { regression } \\
\text { coefficient }\end{array}$ \\
\hline Intercept & 0.20 & $0.00001^{*}$ & 0.00 \\
\hline Purchase ratio & $1.89 \mathrm{E}-07$ & $0.0276^{*}$ & 0.17 \\
\hline Percentage mark-up pricing & -0.06 & $0.0458^{*}$ & -0.16 \\
\hline \multicolumn{4}{|l|}{ Form of business organization: } \\
\hline sole proprietorship & 0.12 & $0.0007^{*}$ & 0.35 \\
\hline partnership & 0.01 & 0.87540 & 0.02 \\
\hline close corporation & -0.07 & 0.0776 & -0.18 \\
\hline $\begin{array}{l}\text { Analysis of strengths and } \\
\text { weaknesses }\end{array}$ & 0.034 & 0.1571 & 0.11 \\
\hline
\end{tabular}

- significant at a confidence level of $5 \%$

Adj $R^{2}=0.1602$ or $16.02 \%$

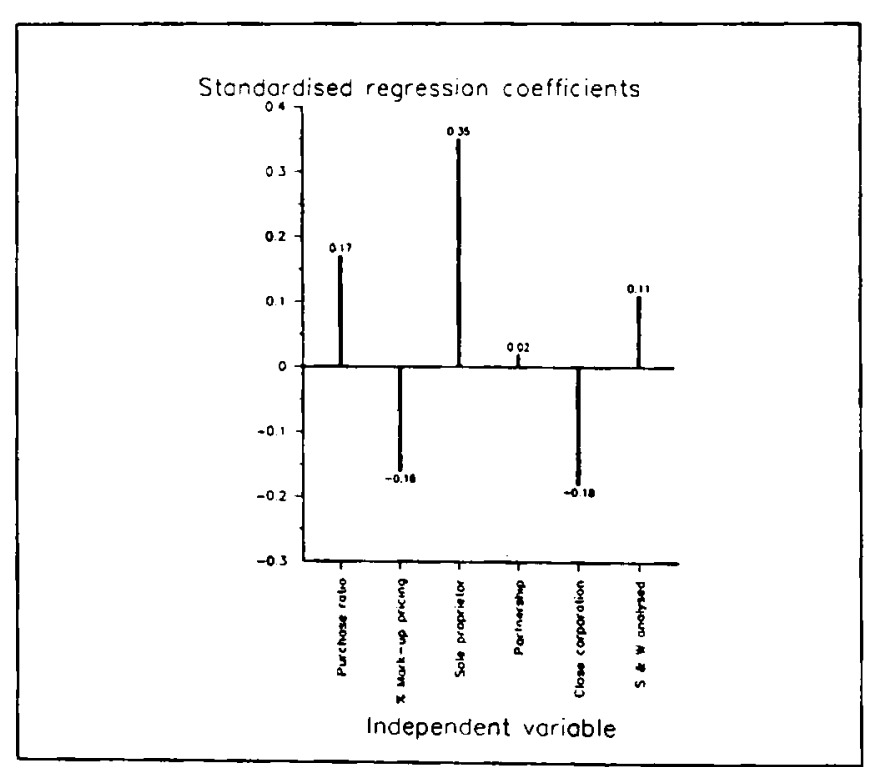

Figure 1 Standardized regression coefficients

The difference in profitability could also be ascribed to the productive use of personnel and the effective management of stock levels.

The influence on ROA of operating as a single proprietorship or a partnership may be ascribed to the tax rate, which is lower for these forms of business organization than that for close corporations. At the time of this study a $50 \%$ tax rate was applicable on the net eamings of close corporations and companies.

The other independent variable which has a significant association with and a positive influence on ROA is the analysis of strengths and weaknesses. This association may be ascribed to the use of a strategic management approach which is aimed at maintaining and improving the profitability of the pharmacy through the effective use of its strengths. Such strengths may include effective purchasing decision making, location in a medical centre, and organizing the pharmacy as a single proprietorship.

The close corporation form of business organization had a significant association with and a negative influence on ROA. This may be ascribed to the tax rate that close cor. porations are subject to. Another independent variable percentage mark-up pricing - emerged as a significant explanatory variable for ROA. Percentage mark-up may be convenient for the pharmacist to use, but it does not take into consideration costs such as carrying cost and delivery costs, or the required rate of return of the pharmacy and competitors' prices for the same products. This could lead to consumer resistance based on the perception that 'pharmacies are too expensive', with a concomitant decrease in sales. Such a decrease in sales could have a negative influence on profitability.

Before embarking on any recommendations as to how retail pharmacists might maintain and improve the profitability of their pharmacies, a few remarks regarding the unique circumstances of each pharmacy are appropriate:

1. Different types of medicines have to be dispensed for the treatment of diseases occurring with varying frequency and at different times of the year in the various geographical areas.

2. The lifestyles and spending patterns of consumers differ from town to town and suburb to suburb.

3. The various promotion chains ${ }^{7}$ may require that participating retail pharmacies promote selected products during certain periods of the year.

Since each pharmacy faces a unique set of circumstances, the following recommendations will not apply to all pharmacies.

\section{A strategic management approach}

It is recommended that a strategic management approach be adopted by retail pharmacists to ensure the profitability and the survival of their pharmacies. The strategic management approach ensures effectiveness (doing the right things) and efficiency (doing things right).

In trying to achieve his mission, goals and objectives, the retail pharmacist has to analyze extemal, uncontrollable variables in order to identify opportunities and threats. Very few opportunities and threats come under his direct control. This does not, however, mean that he should not anticipate and/or respond to opportunities and threats that become salient in his operational, industrial or remote environments.

The pharmacist should also analyze the internal, controllable variables of the pharmacy. The pharmacist does have control over the master, business and functional management strategies of his pharmacy. His managerial and leadership abilities undoubtedly have a bearing on the strengths and weaknesses of the pharmacy. His goal should be to enhance the strengths of the pharmacy and to eradicate its weaknesses in order to ensure its profitability and long-term survival.

With the mission of the pharmacy, the opportunities and threats of the environment and the pharmacy's strengths and weaknesses in mind, the pharmacist should decide upon master, business and functional management strategies and combinations thereof. The decision as to which strategy or combination of strategies to implement will depend on the 
pharmacists' managerial abilities, the human and financial resources at his disposal, and the nature and intensity of the competition he faces.

\section{Purchasing management}

Sound purchasing management requires control of the types, quality and quantity of products purchased. Any stock purchased ties up valuable cash resources, thus purchasing needs to be done sensibly.

It was found that the purchasing ratio is positively associated with above-average profitability. This indicates the importance of sound purchasing management and of the effective use of employees to do purchasing. Employees may order stock if they are well trained in purchasing. This permits the pharmacy to be organized into strategic business units according to the product categories, and employees responsible for each unit be allowed to make their own purchasing decisions. The latter is particularly suitable for pharmacies with high turnover figures and which are situated in metropolitan areas.

\section{Financial management}

From the article it is evident that a pharmacy should preferably be operated as a sole proprietorship and not as a partnership, close corporation or private company.

In the article it was also found that discounts to medical aid schemes have a negative influence on profitability. The implication of this finding is that retail pharmacies should not focus on competing on price. Competition should rather be based on service and on being different from other pharmacies. A strategic management approach may be used to achieve these objectives.

\section{Implications for future research}

The variables found to be significant in this study could be supplemented by other variables related to the management of retail pharmacies and used to construct regression models for prediction purposes. Such regression models could be used advantageously by pharmaceutical groups to predict the expected profitability and feasibility of pharmacies financed by them or to take corrective action (training or consultation) in cases where predicted profitability varies significantly from actual profitability.
The gross profit per square meter per product category should be analyzed. A researcher in cost accountancy should ideally undertake such a project. Such a study could apply marginal costing and be undertaken with a view to determining the feasibility of continuing the marketing of front shop items in retail pharmacies. This is necessary in a consumer market which is price sensitive, and where retail pharmacies face competitors like 'Clicks' who have the resources to promote and market such products relatively more effectively.

\section{Notes}

1. The remainder of the article refers to the retail pharmacist as 'him', 'he' or 'his' (male gender). This is done for ease of reading, and all references to the male gender should be taken to include the female gender.

2. See also Justis et al. (1985: 13-14).

3. Area here means province and whether the pharmacy is located in a metropolitan area, city or town.

4. Bonus, Family Circle, Link, Plus pharmacy or other.

5. The residual analysis was graphically done by means of the REG and PLOT procedures of SAS.

6. Usually values like 0,1 and -1 .

7. Family Circle, Link, Plus, Bonus, etc.

8. For the significance of the regression coefficient.

\section{References}

Byars, L.L. 1987. Strategic management: planning and implementation, concepts and cases. New York: Harper \& Row.

Futter. W.T. 1990. I'm thinking of buying a pharmacy: a practical guide to successful small business management. Cape Town: Arrow.

Justis, R.T., Judd, R.J. \& Stephens, D.B. 1985. Stralegic management and policy. Englewood Cliffs, New Jersey: PrenticeHall

Kleinbaum, D.G. \& Kupper, L.L. 1978. Applied regression analysis and other multivariate methods. Boston, Mass: Duxbury.

Pearce, J.A. II \& Robinson, R.B. 1988. Formulation and implementation of competitive strategy. 3rd edition. Homewood: Irwin.

Steiner, G.A., Miner, J.B. \& Gray, E.R. 1986. Management policy and strategy. 3rd edition. New York: Macmillan.

University of Pretoria. 1983. Bedryfsvergelykende ondersoek: Kleinhandelsapteke in Suid-Afrika, 1980. Pretoria: Bureau of Financial Analysis, Report B22, 162p. 